\title{
The match/mismatch hypothesis and the feeding success of fish larvae in ice-covered southeastern Hudson Bay*
}

\author{
Louis Fortier ${ }^{1}$, Dominique Ponton ${ }^{2}{ }$ Michel Gilbert ${ }^{3}$ \\ ${ }^{1}$ Département de biologie, Université Laval, Ste-Foy, Québec, Canada G1K 7 P4 \\ ${ }^{2}$ ORSTORM, Route de Montabo, CP 165, 97323 Cayenne, Guyane française \\ ${ }^{3}$ Institut Maurice-Lamontagne, Ministère des Pêches et des Océans, CP 1000, Mont-Joli, Québec, Canada G5H $3 Z 4$
}

\begin{abstract}
We studied the synchronism between the seasonal occurrence of fish larvae and their prey in ice-covered southeastern Hudson Bay, Canada, in spring 1988, 1989 and 1990. Arctic cod Boreogadus saida and sand lance Ammodytes sp. larvae hatched several weeks before ice break-up and fed primarily on copepod nauplii. The timing of $50 \%$ yolk resorption was the same every year (11 to 18 May for Arctic cod and 5 to 11 June for sand lance) but the availability of copepod nauplit varied substantially between years, both in magnitude ( 7 -fold) and timing ( 4 to $6 \mathrm{wk}$ ). Interannual differences in the under-ice abundance of nauplii were linked to variations in the abundance of female cyclopoid copepods, and appeared unrelated to the timing of the ice-algal or phytoplankton blooms. Interannual differences (2-to 4 -fold) in the feeding success of fish larvae (percent feeding incidence at length and mean feeding ratio at length) were related to the availability of copepod nauplii. Consistent with the match/mismatch hypothesis, the fixity of the spawning season in relation to a variable cycle of prey abundance accounted for the observed variations in feeding success and apparent growth (length at date) of fish larvae. Yet, in this particular ecosystem, a match or mismatch between Arctic cod or sand lance larvae and their prey may depend more on the dynamics of cyclopoid copepods during the previous winter than on the timing of the spring algal blooms.
\end{abstract}

KEY WORDS: Match/mismatch - Fish larvae - Feeding success · Boreogadus saida A Ammodytes . Hudson Bay

\section{INTRODUCTION}

Hjort (1914) suggested that year class strength in marine fish is determined at yolk resorption when the first-feeding planktonic larvae have not yet fully developed their foraging abilities and are most vulnerable to starvation. A lack of suitable prey during this critical developmental stage would result in massive mortality. The production of copepod eggs and nauplii (usually the major prey of first-feeding fish larvae) is often linked to the production of diatoms (see Kiørboe 1991 and Fortier et al. 1992 for reviews). Cushing (1974,

\footnotetext{
- Contribution to the research programs of GIROQ (Groupe interuniversitaire de recherches océanographiques du Québec) and Institut Maurice-Lamontagne (Ministère des Pêches et des Océans)
}

1975) coupled Hjort's critical-period concept to the critical-depth model of Gran \& Braarud (1935) and Sverdrup (1953), which explains the moment and duration of the spring and autumn diatom blooms in temperate waters. The resultant match/mismatch hypothesis proposes that variations in year class strength are rooted in the fixity of the spawning time of marine fish in relation to a variable phytoplankton bloom. Since spawning is adapted to median conditions, a bloom centred on the long-term median date will generate a strong year class while exceptionally early or late blooms will result in poor recruitment. According to the hypothesis, an initial mismatch between the mouth aperture of fish larvae and the average cephalothorax width of their copepod prey would hamper foraging efficiency not only at first feeding but during the entire co-development of the young fishes and their prey (Jones 1973). 
Slow growth due to reduced feeding success would lengthen the period of vulnerability of fish larvae to predators, thus increasing total cumulative mortality in the first months of life (Cushing \& Harris 1973, Shepherd \& Cushing 1980, Anderson 1988, Cushing 1990, Cushing \& Horwood 1994)

The timing between the occurrence of fish larvae and their prey could be particularly critical in seasonally ice-covered arctic and subarctic seas where the season of biological production is short (Cushing 1975, Drolet et al. 1991). In subarctic Hudson Bay, Canada, the larvae of 14 fish species occur before the break-up of the winter ice cover (Ponton et al. 1993). Arctic cod Boreogadus saida and sand lance Ammodytes sp., which numerically dominate the ichthyoplankton assemblage, are the earliest species to emerge. The larvae first appear at the onset of biological production in early May, when ice algae start to grow at the ice-water interface (Drolet et al. 1991, Ponton et al. 1993).

We monitored the abundance and feeding success of Arctic cod and sand lance larvae in relation to the vernal development of ice algae and phytoplankton, and the density of microzooplankton prey in 1988 , 1989 and 1990, in the area of southeastern Hudson Bay influenced by the freshwater plume of the Great Whale River. In the present study, we address the assumptions and predictions of the match/mismatch hypothesis concerning the timing and fixity of larval fish production, the variability of algal blooms and copepod reproduction, and the impact of interannual variations in prey density on the feeding success of fish larvae emerging before the ice breakup. The role of river plume dynamics and other factors (depth, light, temperature, time of day, potential predators) in determining prey availability and the feeding success of Arctic cod and sand lance larvae in southeastern Hudson Bay is discussed in a separate analysis (Fortier et al. in press).

\section{MATERIALS AND METHODS}

Study area. Hudson Bay (Fig. 1) is a large shallow subarctic inland sea covered with annual ice from December to early June. Residual circulation in the bay is cyclonic and slow ( 3 to $5 \mathrm{~cm} \mathrm{~s}^{-1}$ ) (Prinsenberg 1986, Lepage \& Ingram 1991). Biological production starts in early April when light becomes sufficient for microalgae (mostly diatoms) to grow at the bottom of the ice and at the ice-water interface (e.g. Gosselin et al. 1985, Michel et al. 1993). The ice algae support an ice meiofauna comprised of bacteria, nematodes, amphipods and harpacticoid copepods (Grainger 1988). Some calanoid copepods emerge from winter

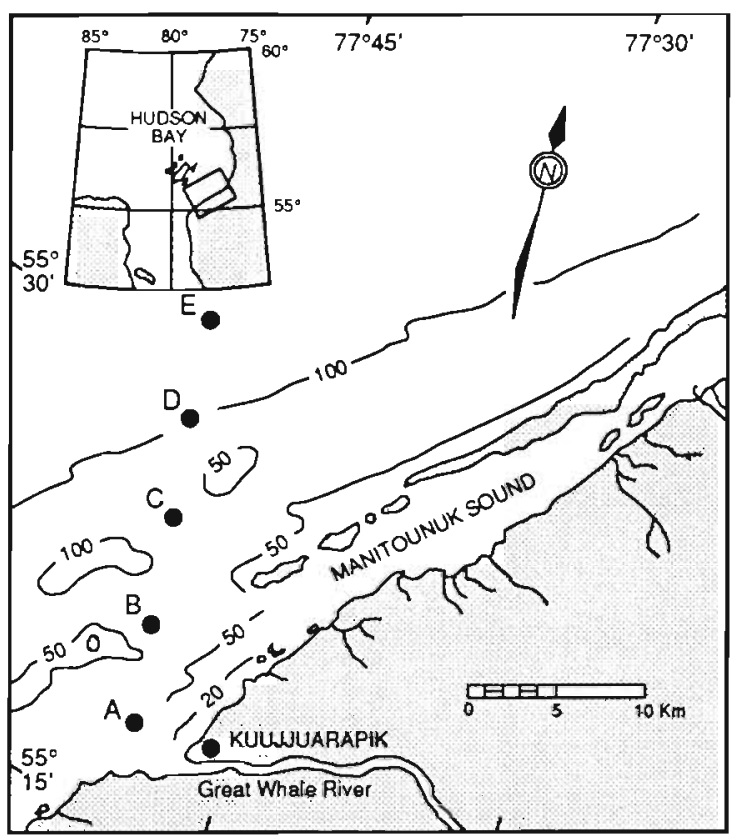

Fig. 1. Southeastern Hudson Bay, Canada, showing the location of sampling Stations A to E Depth at Stations A to E was $35,65,70,100$ and $140 \mathrm{~m}$ respectively. Isobaths are in metres

diapause, metamorphose into adults and start to reproduce as soon as the ice algae develop (Runge \& Ingram 1991, Runge et al. 1991). The phytoplankton bloom is triggered several weeks after the onset of ice-algal production, when the break-up of the ice cover allows light to penetrate the surface layer (Drolet et al. 1991, Michel et al. 1993).

The study was conducted off the mouth of the Great Whale River in southeastern Hudson Bay (Fig. 1) In spring and early summer, a major hydrographic feature of the area is the 3 to $5 \mathrm{~m}$ thick brackish plume formed by the freshwater outflow of the river into the bay. With the ice cover preventing the vertical mixing by wind of the brackish plume with the underlying marine layer, the plume may extend over $1000 \mathrm{~km}^{2}$ during the freshet (Ingram \& Larouche 1987).

Sampling. To cover the salınıty and turbıdity gradients associated with the river plume, sampling stations ranging in depth from 35 to $140 \mathrm{~m}$ were positioned at intervals of about $5 \mathrm{~km}$ along a northward transect starting near the mouth of the river (Fig 1). Of these, 4 stations were occupied regularly in 1988 (A, B, C, D), 2 in 1989 (B, E) and 3 in 1990 (A, B, E) (Fig. 1) Between-station variabllty and the effect of the river plume on the feeding of fish larvae are considered in detail elsewhere (Gilbert et al. 1992, Fortier et al. in press). Between-station variability was less than seasonal and interannual variability, and, in the present study, the data from the different stations were pooled 
to assess the seasonal pattern in the abundance of fish larvae and their prey for the 3 years.

Details of the sampling methodology are given in Drolet et al. (1991), Gilbert et al. (1992), and Ponton et al. (1993). In summary, ice stations were reached by snowmobile every 2 nd or 3rd day from mid April until the ice break-up in late May or early June. Vertical profiles of salinity and temperature were recorded with a CTD. SCUBA divers used suction guns to collect ice algae at the ice-water interface (Tremblay et al. 1989). Phytoplankton samples were obtained from different depths with a submersible pump. A $64 \mu \mathrm{m}$ mesh plankton net was towed from the bottom to the surface to estimate the areal density of the microzooplankton prey of fish larvae (mainly copepod eggs and nauplii) and copepods. To capture fish larvae, a sampler consisting of 2 plankton nets $\left(500 \mu \mathrm{m}\right.$ mesh, $1 \mathrm{~m}^{2}$ mouth aperture, TSK flowmeters, time-depth recorder) mounted on a metal frame was towed horizontally at an average speed of $1.3 \mathrm{~m} \mathrm{~s}^{-1}$, over a distance of $200 \mathrm{~m}$ $(1988,1989)$ or $150 \mathrm{~m}$ (1990) between 2 apertures in the ice cover using a heavy-duty snowmobile. Two free-wheeling spherical buoys mounted on the frame kept the sampler immediately under the ice cover to sample the 0.5 to $1.5 \mathrm{~m}$ depth interval in the brackish river plume. Removing the buoys allowed us to sample at 8 to $10 \mathrm{~m}$ in the marine layer underlying the brackish plume. Both depth intervals $(0.5$ to 1.5 and 8 to $10 \mathrm{~m}$ ) were sampled in succession at each station.

After the ice break-up, a helicopter mounted on floats or a small boat were used to reach ice-free areas in the vicinity of the original stations. Sampling was pursued at intervals of $2 \mathrm{~d}$ until mid June, except in 1989 when operations were terminated on 31 May. Temperature, salinity, phytoplankton and microzooplankton were sampled as described above. Fish larvae were collected with a $1 \mathrm{~m}$ diameter conical net (500 $\mu \mathrm{m}$ mesh) towed horizontally with the helicopter or the boat (once at the surface and then at $8 \mathrm{~m}$ ). All ice and open water stations were visited in daylight, between 09:00 and 19:00 h. Daily outflow data at the mouth of the Great Whale River (Station 093801) were kindly supplied by the Division des réseaux hydriques, Ministère de l'Environnement du Québec.

Samples for the determination of algal biomass were filtered on GF/F filters, and chlorophyll a concentrations were determined with a fluorometer after $24 \mathrm{~h}$ extraction in $90 \%$ acetone at $5^{\circ} \mathrm{C}$. Zooplankton samples were preserved in $4 \%$ buffered formalin in seawater. To minimize gut content evacuation, fish larvae were anaesthetized with MS-222 prior to fixation. All fish larvae were sorted from the $500 \mu \mathrm{m}$ mesh samples (horizontal tows). Standard length (after preservation) and the presence of a yolk-sac were assessed for all Arctic cod and sand lance larvae. For both species, a subset of larvae (up to 50 depending on availability, on average 11.4 per sample) was taken at random from each sample for the determination of gut content. Prey were excised, measured (width and length) and identified whenever possible. Body (prosome) width and length of copepod nauplii prey were measured with an electronic micrometer (resolution of $1 \mu \mathrm{m}$ ) at a magnification of $50 \times$. Percent feeding incidence (percentage of larvae with a least 1 prey in the gut) and mean feeding ratio (mean number of prey per gut) were calculated for samples containing 5 larvae or more. Copepods and the microzooplankton prey of fish larvae were identified and enumerated in the $64 \mu \mathrm{m}$ mesh samples (vertical tows). The width and length of copepod nauplii in the plankton collections were measured as above.

\section{RESULTS}

\section{Hydrography, algal blooms, and copepod nauplii}

In southeastern Hudson Bay, the freshet of the Great Whale River is a good indicator of the vernal warming which precedes the break-up of the ice cover on the bay. The freshet occurred earlier in 1988 than in 1989 or 1990 (Fig 2a to c). In 1988, the increase in river outflow started around 20 April and reached its maximum on 12 May (Fig. 2a). The break-up of the ice cover (when leads multiply and floes separate) started on 20 May, allowing light to penetrate the surface layer. In 1989, river outflow reached its maximum on 23 May, 11 d later than in 1988, and the break-up of the ice cover on the Bay started around 7 June, 18 d later than in 1988 (Fig. 2b). In 1990, maximum river flow (23 May) and ice break-up (5 June) were again late relative to 1988 (Fig. 2c). In all years, temperature varied little as long as the ice cover persisted, with values of $0^{\circ} \mathrm{C}$ in the brackish river plume ( 0 to $5 \mathrm{~m}$ ) and $-1^{\circ} \mathrm{C}$ in the underlying marine layer (Fig. $2 d$ to f).

Depending on the year, the density of ice algae at the ice-water interface reached a maximum in mid- to late April (Fig, $2 g$ to i). Algal biomass in the river plume ( 0 to $5 \mathrm{~m}$ layer) was already high at the beginning of our sampling in 1988 (Fig. 2j) but did not increase until mid May in 1989 and 1990 (Fig. 2k, l). The phytoplankton bloom in the water column under the river plume started in the first week of June in 1988 and 1990 (Fig. $2 \mathrm{~m}, 0$ ). Our sampling stopped before the phytoplankton bloom in 1989 .

Over the 3 years of sampling, the assemblage of copepodites and adult copepods was dominated numerically by egg-bearers such as Oithona similis (49.6\%), Oncaea borealis (26.0\%), and Pseudocalanus spp. $(15.1 \%)$. Copepodites of these species were 


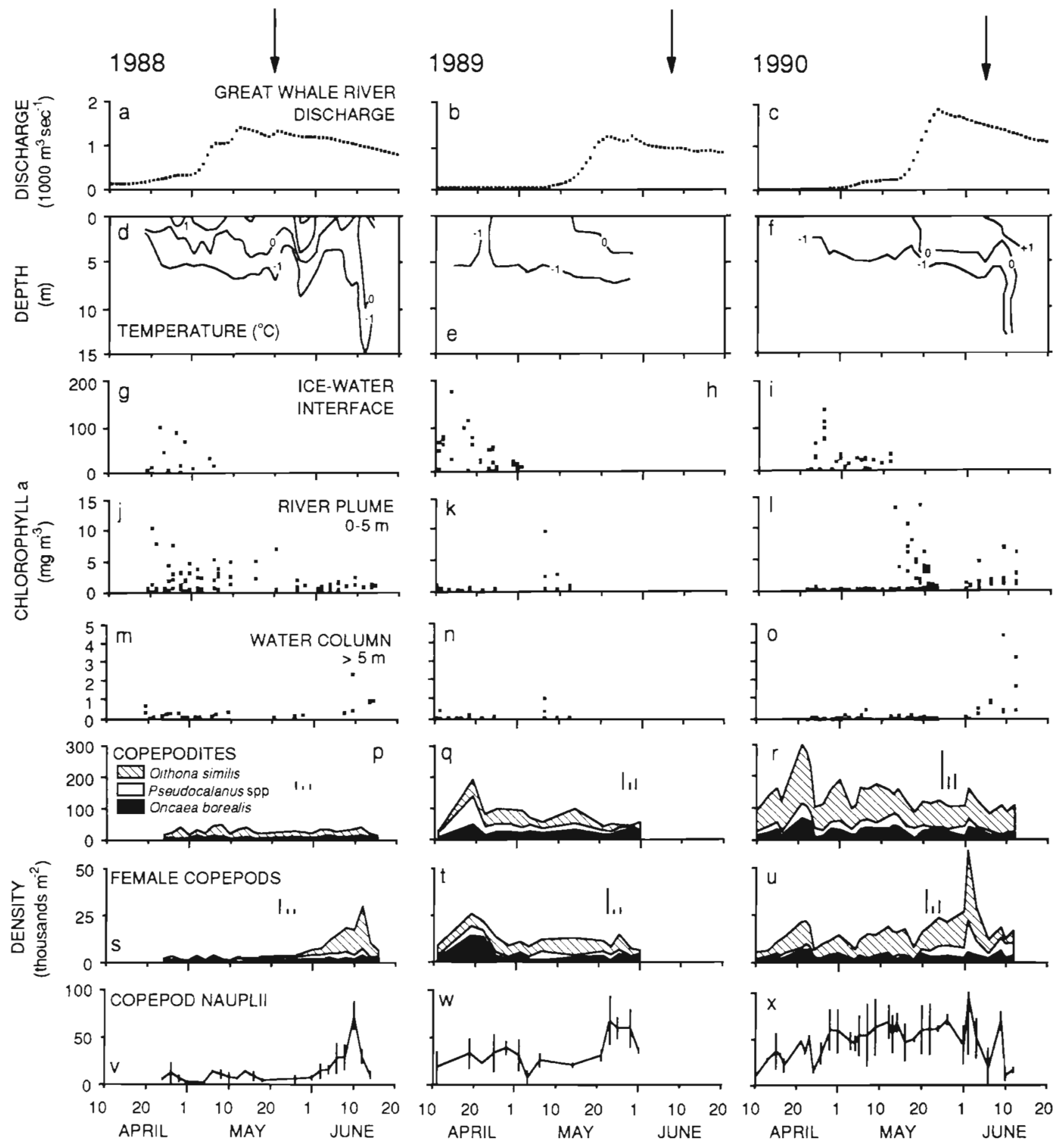

Fig. 2. Southeastern Hudson Bay in spring. Interannual comparison of (a to $c$ ) the timing of the Great Whale River freshet, ( $\mathrm{d}$ to $\mathrm{f}$ ) the temperature regime under the ice cover at station $B$, ( $g$ to i) the biomass of ice algae and ( $j$ to l) phytoplankton in the river plume and ( $\mathrm{m}$ to $\mathrm{o}$ ) in the water column, ( $\mathrm{p}$ to r) the areal density of copepodites, ( $\mathrm{s}$ to $\mathrm{u}$ ) female copepods and ( $\mathrm{v}$ to $\mathrm{x}$ ) copepod nauplii ( \pm 1 standard deviation). All values of microalgal biomass available for each station were plotted. Zooplankton densities are averages of 4 (1988), 2 (1989) or 3 (1990) stations. The 3 vertical bars associated with copepodite and female copepod densities ( $p$ to $u$ ) correspond to 2 average standard deviations in the density of Oithona similis, Pseudocalanus spp. and Oncaea borealis from left to right respectively, and represent between-station variability. Vertical arrows indicate the beginning of the ice 
already present in late April several weeks before the phytoplankton bloom (Fig. $2 p$ to r). The seasonal pattern of copepodite abundance varied in timing and amplitude between years, and these variations were reflected in the density of female copepods (Fig. 2s, t) and copepod nauplii (Fig. 2v to x). In 1988, the density of copepodites remained relatively low throughout the sampling period and female abundance did not increase until late May / early June (Fig. 2p, s). Accordingly, the density of nauplii was relatively low and increased only in early June (Fig. 2v). In 1989, copepodites and nauplii were more abundant and occurred earlier (ca 4 wk) than in 1988 (Fig. 2q \& w). In 1990, high densities of copepodites occurred early in the season (Fig. 2r), and the density of nauplii increased about 6 wk earlier than in 1988 (Fig. $2 x$ ). The median density of copepod nauplii was $7.3,33.4$, and $50.6 \times 10^{3} \mathrm{~m}^{-2}$ for 1988 ( $n=65$ day-stations), $1989(n=50)$ and 1990 ( $n=$ $66)$ respectively. Variations among stations in the abundance of copepodites, female copepods or nauplii were small relative to seasonal and interannual variations (Fig. 2p to $\mathrm{x}$ ).

There was no obvious link between interannual variations in the timing and level of microalgal biomass and interannual variations in the seasonal pattern of abundance of copepodites or nauplii. For example, the ice algal bloom occurred roughly at the same time and with the same intensity in 1988 and 1990, but copepodite emergence and the abundance of nauplii were minimum in 1988 and maximum in 1990 (Fig. 2). Similarly, the accumulation of substantial algal biomasses in the river plume (0 to $5 \mathrm{~m}$ ) occurred $3 \mathrm{wk}$ earlier in 1988 than in 1990 , but significant copepod reproduction started 6 wk later than in 1990. Finally, the increase in the biomass of nauplii coincided with the increase in phytoplankton in the deep layer in 1988, but copepod nauplii occurred well before the phytoplankton bloom in 1989 and 1990.

\section{Seasonal occurrence and diet of Arctic cod and sand lance larvae}

Arctic cod Boreogadus saida and sand lance Ammodytes sp. represented 56.4 and $34.4 \%$ respectively of all fish larvae collected along the sampling transect over the 3 years. A majority of the larvae of both species were captured in the 8 to $10 \mathrm{~m}$ depth interval (Fig. 3). In any year, the 2 species were present several weeks before the ice break-up. Background densities of $<1$ larvae $100 \mathrm{~m}^{-3}$ were observed for both species at the onset of sampling in late April of each year. Except for sand lance in 1988, densities did not increase until the first days of May (Fig. 3). This timing varied remarkably little among the 3 years sampled.

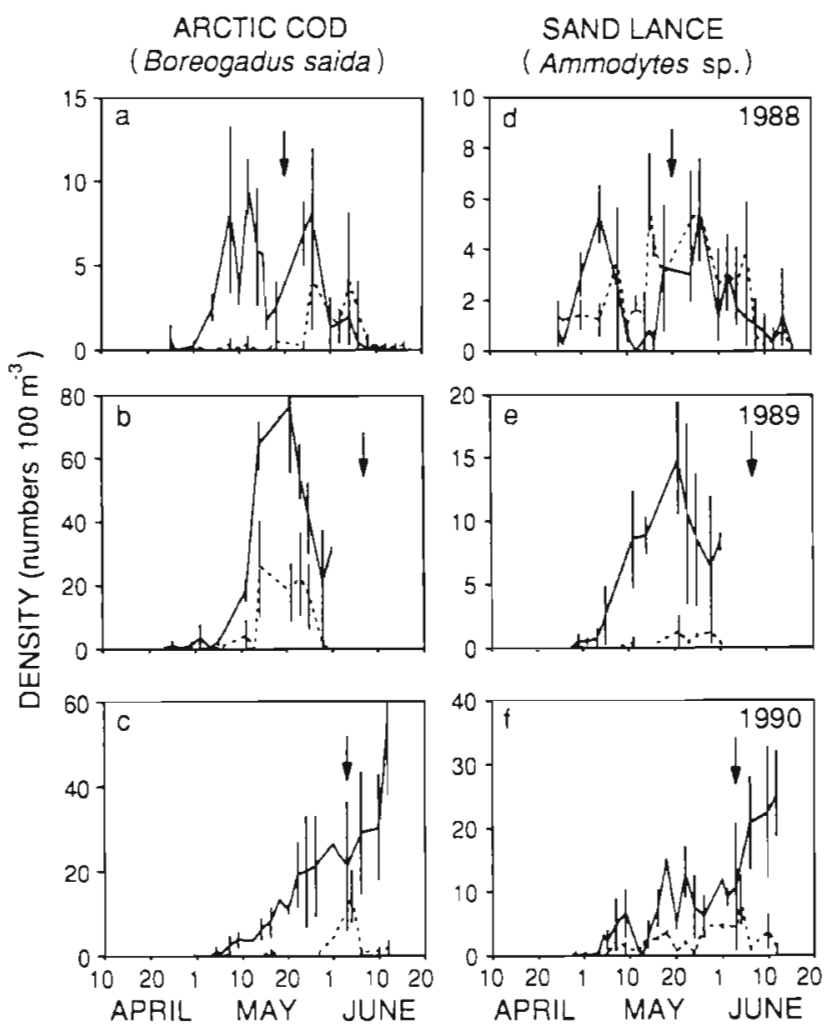

Fig. 3. Boreogadus saida, Ammodytes sp. Time series of (a to c) Arctic cod and (d to e) sand lance density in the 0.5 to $1.5 \mathrm{~m}$ (dotted line) and 8 to $10 \mathrm{~m}$ depth layers (continuous line) in southeastern Hudson Bay in 1988, 1989 and 1990. Densities are the average ( \pm 1 standard deviation) of 4 stations in 1988 , 2 in 1989 and 3 in 1990. Note the different scales for density. Vertical arrows indicate the beginning of the ice break-up in Hudson Bay

Relatively few Arctic cod larvae were captured at any time in 1988 (Fig. 3a). Densities increased sharply in mid-May in 1989 (Fig. 3b) and more regularly over the entire sampling period in 1990 (Fig. 3c). In 1988, sand lance abundance peaked first in early May and then again in late May before densities declined to nearzero values in early June (Fig. 3d). In 1989 and 1990, densities increased regularly until the end of our sampling (Fig. 3e, f). Interestingly, patterns of abundance for a given year were similar for the 2 species, suggesting that the same forcing (e.g. large-scale advection) affected the regional abundance of Arctic cod and sand lance. Variations among stations were small relative to seasonal and interannual variations (Fig. 3).

The length-frequency distribution of Arctic cod and sand lance presented a single and usually well-defined mode, indicating that only 1 cohort of larvae was produced in the spring of each year (Fig. 4). The limited range of length observed over the 6 to $8 \mathrm{wk}$ of sampling in each year $(<6 \mathrm{~mm})$ indicated that growth was slow. For a given year, the overall proportion of yolk- 


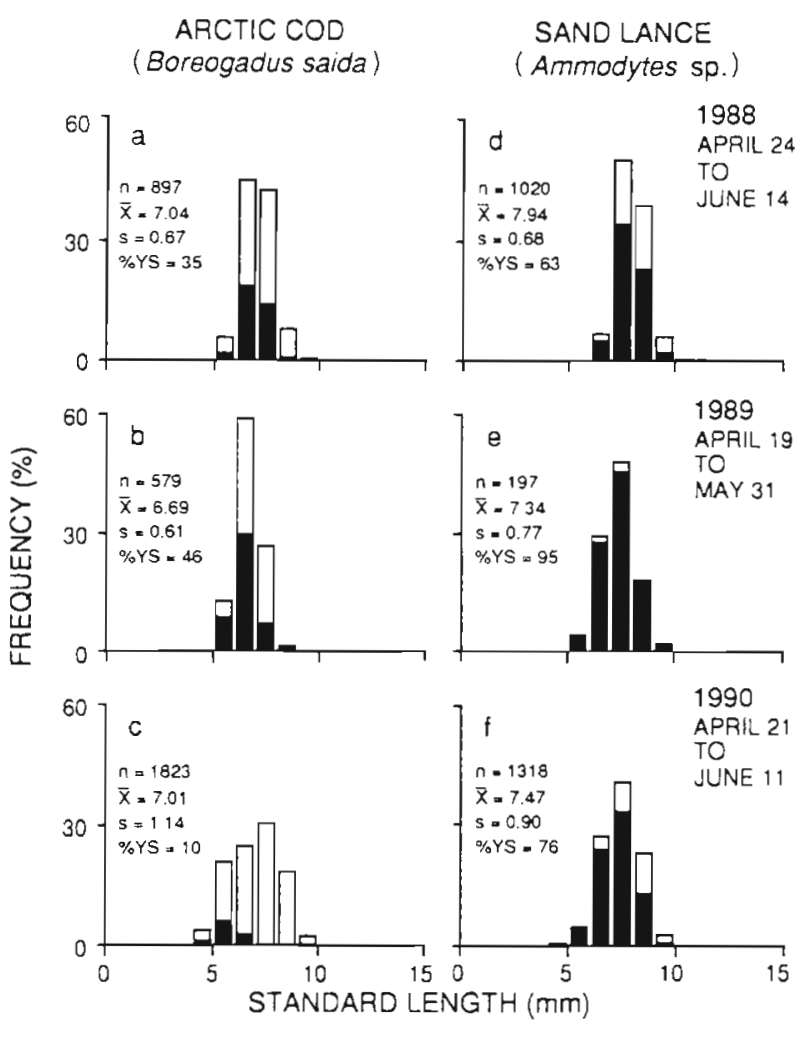

Fig. 4. Boreogadus saida, Ammodytes sp. Length frequency distributions of Arctic cod and sand lance larvae collected in southeastern Hudson Bay by year. The black fraction of the histogram indicates the percentage of yolk-sac larvae. The number of larvae measured $(n)$, the average length. $(\bar{X})$, the standard deviation (s) and the percentage of yolk-sac larvae (\%YS) are given

sac larvae was always greater in sand lance than in Arctic cod (Fig. 4). In 1989, shorter lengths and higher yolk-sac frequencies for both species (Fig. $4 \mathrm{~b}, \mathrm{e}$ ) reflected the early termination of our sampling, the longer post yolk-sac larvae normally collected in June not being sampled in this year. Yolk-sac frequency was unusually low in Arctic cod in 1990 (Fig. 4c).

Arctic cod and sand lance larvae preyed primarily on copepod nauplii (Table 1). Copepod eggs, tintinids, algal cells (diatoms and Peridinium sp.) and mollusc larvae were consumed in small proportion. The diet of both species tended to be more diversified in 1988 than in 1990. Diet diversity was similar in 1989 and 1990 for Arctic cod. In 1989, sand lance larvae were mostly yolk-sac larvae and very few prey were found in their gut. The termination of our sampling before a majority of the larvae initiated feeding may explain the low diet diversity for that species in that year, only the most frequent prey taxa being represented among the few prey dissected (Table 1)

The body length of copepod nauplii ingested by Arctic cod and sand lance larvae ranged from 70 to 449
Table 1. Boreogadus saida, Ammodytes sp. Percent composition (by number) of the diet of Arctic cod and sand lance Larvae by year. The number of larvae analysed and the number of prey found are given

\begin{tabular}{|lrrrrrr|}
\hline & \multicolumn{3}{c}{ Arctic cod } & \multicolumn{3}{c|}{ Sand lance } \\
& 1988 & 1989 & 1990 & 1988 & 1989 & 1990 \\
\hline Copepod nauplii & 67 & 95 & 82 & 37 & 97 & 52 \\
Copepod eggs & 12 & $<1$ & 12 & 7 & 0 & 21 \\
Tintinids & 4 & 0 & 0 & 18 & 0 & 15 \\
Algal cells & 5 & 4 & 1 & 20 & 0 & 2 \\
Mollusc larvae & $<1$ & 0 & 2 & 1 & 3 & 6 \\
Other eggs & 3 & 0 & 0 & 6 & 0 & 0 \\
Copepodites & $<1$ & 0 & 2 & 1 & 0 & 0 \\
Rotifers & 0 & 0 & 0 & 1 & 0 & 0 \\
Others & 8 & 0 & 1 & 10 & 0 & 4 \\
& & & & & & \\
No. of larvae & 897 & 579 & 592 & 1020 & 197 & 876 \\
No. of prey & 461 & 602 & 1672 & 217 & 19 & 445 \\
\hline
\end{tabular}

and 69 to $289 \mu \mathrm{m}$ respectively. Comparing these ranges with the reported specific body length of known copepod nauplii indicated that genera such as Oithona, Pseudocalanus and the smaller Oncaea (the 3 genera that numerically dominated the copepod assemblage) contributed the bulk of the nauplii eaten by Arctic cod and sand lance larvae (Fig. 5). In Arctic cod, $75.9 \%$ of the nauplii ingested were smaller (or equal) in body length than the average Oncaea similis NVI, whereas $21.8 \%$ of them were longer than Calanus finmarchicus NI. In sand lance, these percentages were $95.1 \%$ and $4.9 \%$ respectively. Calanus glacialis, the Calanus present in Hudson Bay, produces larger eggs than its sibling species $C$. finmarchicus $(175 \pm 6 \mu \mathrm{m}$ vs $146 \pm 8 \mu \mathrm{m}$; Hirche \& Bohrer 1987) and presumably larger nauplii. Thus, using the body length of $C$. finmarchicus nauplii as a conservative minimum estimate of the body length of C. glacialis nauplii, only the smallest naupliar stages (NI to NIII) of the latter could have been preyed upon by Arctic cod larvae (Fig. 5).

Nauplii in the gut of fish larvae were conspicuously flattened laterally and dorso-ventrally. The slope of the regression of body width $(W$, in $\mu \mathrm{m}$ ) on length $(L)$ was significantly weaker (ANCOVA, $p=0.0009$ ) for nauplii in the gut of Arctic cod $\left(W=28+0.361 L, \mathrm{r}^{2}=0.511, \mathrm{n}=\right.$ 1014) and sand lance larvae $\left(W=24+0.285 L, r^{2}=\right.$ $0.390, n=143$ ) than for nauplii collected in the plankton $\left(W=-10+0.590 L, r^{2}=0.827, \mathrm{n}=450\right)$. This lateral compression prevented any direct comparison of width between nauplii prey and nauplii retained by the $64 \mu \mathrm{m}$ mesh plankton net. Assuming that body length was unaffected by ingestion, the actual width of nauplii prey was estimated from their length using the width-length relationship for nauplii in the plankton net. The comparison of the frequency distributions of 


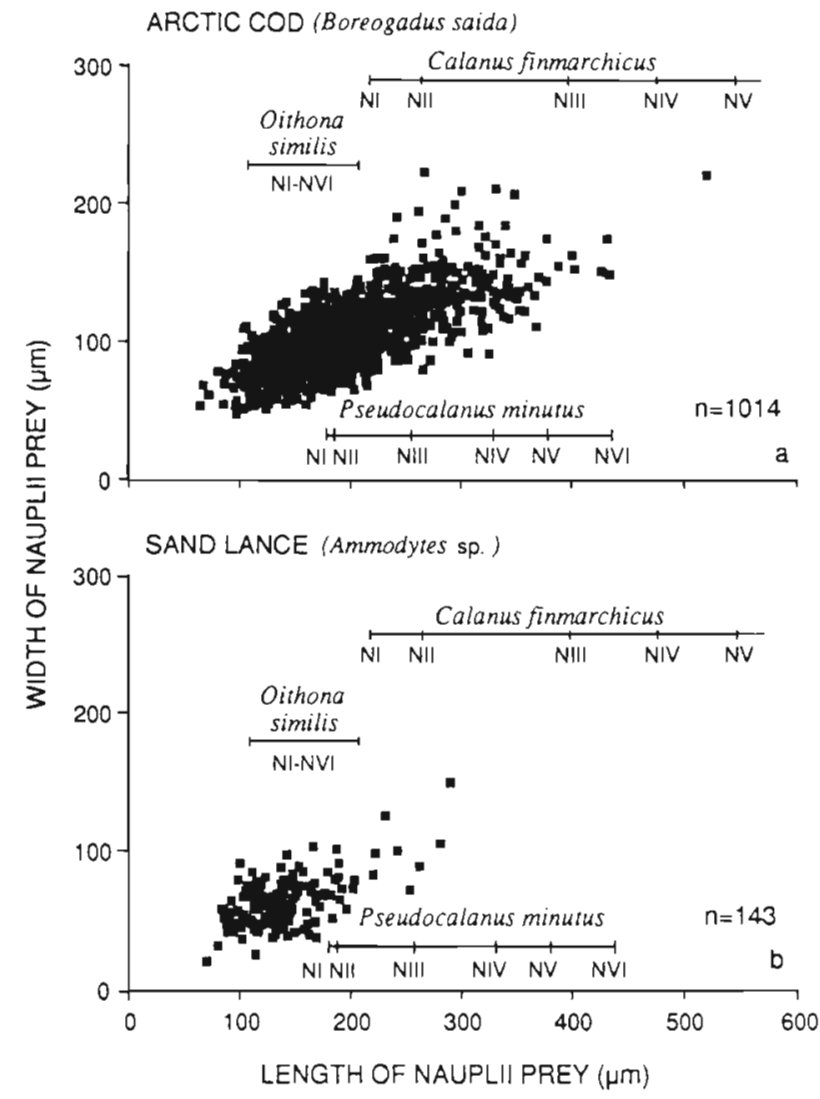

Fig. 5. Boreogadus saida, Ammodytes sp. Body (prosome) width versus body length of copepod nauplii ingested by (a) Arctic cod and (b) sand lance larvae in southeastern Hudson Bay in 1990. Horizontal lines represent the average body length range of the naupliar stages (NI to NVI) of Calanus finmarchicus and Pseudocalanus minutus (Ogilvie 1953), and Oithona similis ( $=$ helgolandica, Lovegrove 1956)

nauplii width in the plankton and in the gut of Artic cod larvae indicated that the plankton net quantitatively retained the nauplii eaten by Arctic cod larvae (Fig. 6a, b). Small nauplii were considerably more frequent in the gut of sand lance larvae than in the plankton net (Fig. 6a, c). The difference in the frequency distributions may reflect the selection by sand lance larvae of the smallest nauplii available, the poor retention by the net of nauplii $<64 \mu \mathrm{m}$, or a combination of both. If small nauplii were poorly retained by the net, the availability of nauplii prey to sand lance larvae may have been underestimated.

\section{Yolk-sac resorption and apparent growth}

In Arctic cod larvae, angular-transformed yolk-sac frequency declined linearly with time and length (Fig. 7). The rate of decline in yolk-sac frequency with time varied little between years (ANCOVA, $F=2.31$, $p=0.114$ ) (Fig. 7a to c). Yolk-sac resorption at the level of the population ( $50 \%$ of the larvae with no more yolk) occurred at about the same date every year 15,18 and 11 May in 1988, 1989, and 1990 respectively. The exclusion of 1 outlier data point for 1990 (circled on Fig. 7c) yields an estimate of 16 May for that year, further reducing interannual variability in the estimated date of $50 \%$ yolk resorption. The linear regression of yolk-sac frequency on length suggested that the physiological utilization of yolk reserves was slower in 1988 compared to 1989 and 1990 (ANCOVA, $F=84.7, p<$ 0.0001 ) (Fig. $7 d$ to f). In 1990, 50\% yolk resorption occurred at a smaller length $(4.7 \mathrm{~mm})$ than in 1988 (5.6 mm) or 1989 (6.5 mm).

In sand lance larvae, the angular transformation of yolk-sac frequency did not linearize the relationships between yolk-sac frequency and date or fish length. In 1988, yolk-sac frequency declined from the onset of our sampling and $50 \%$ resorption occurred on 5 June (Fig. 8a). In 1989 yolk-sac frequency remained high (>80\%) until the end of sampling on 31 May (Fig. 8 b). In 1990 yolk-sac frequency did not decrease until the end of May, and 50\% resorption was predicted to occur on 11 June (Fig. 8c). In 1988, 50\% resorption occurred at $8.7 \mathrm{~mm}$ and in 1990 at $8.6 \mathrm{~mm}$ (Fig. 8d, f).

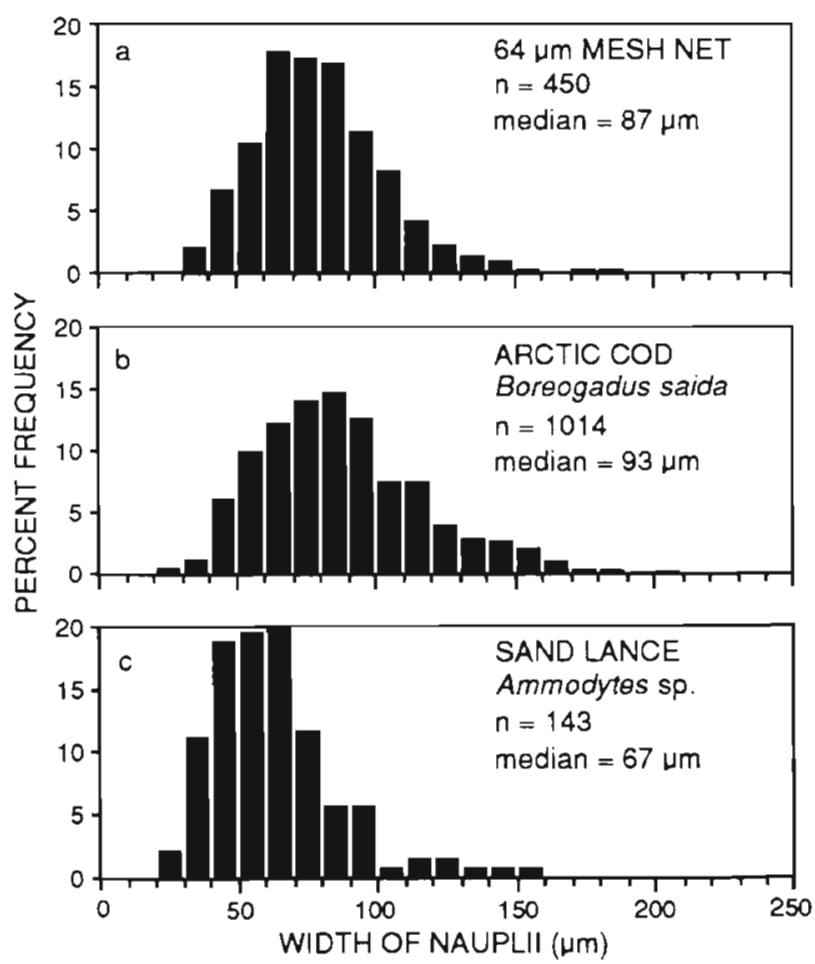

Fig. 6. Frequency distribution of the body width of nauplii (a) in the $64 \mu \mathrm{m}$ mesh plankton net, and (b) in the gut of Arctic cod and (c) sand lance larvae in southeastern Hudson Bay in 1990 . Body width of nauplii prey $(b, c)$ was corrected for lateral compression due to the ingestion process (see text) 


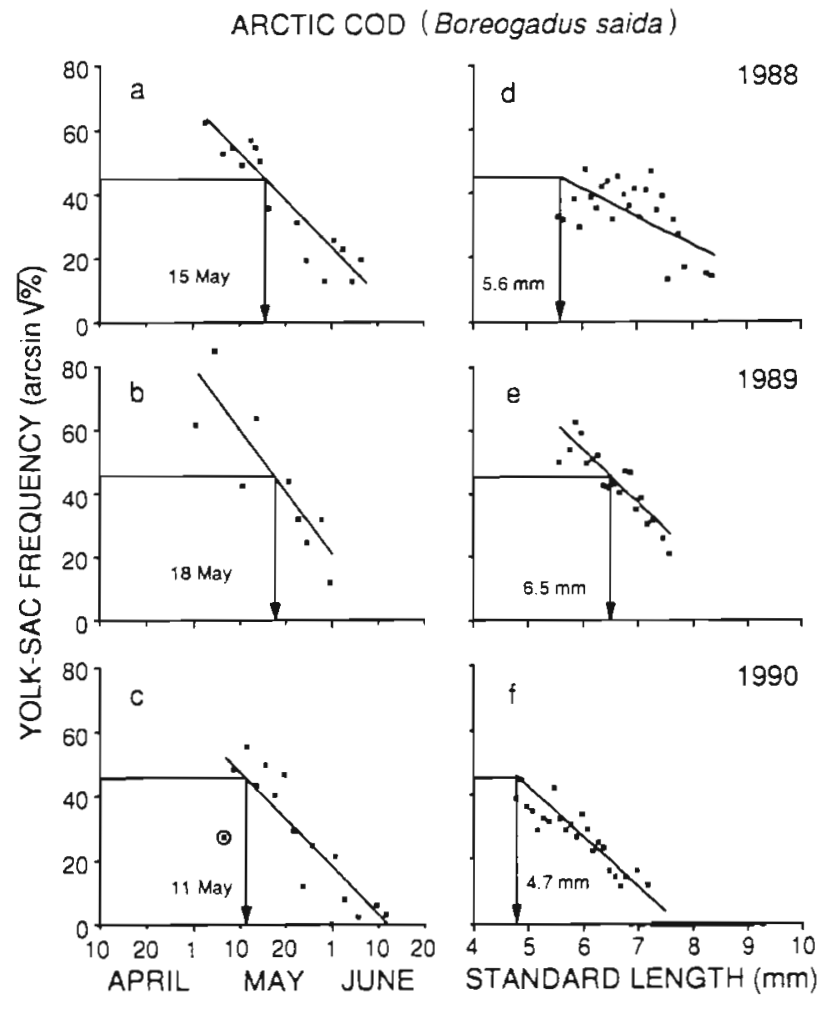

Fig. 7. Boreogadus saida. Yolk-sac frequency in Arctic cod larvae as a function of (a to $c$ ) date and ( $d$ to $f$ ) standard length by year. Only those data points representing at least 5 larvae were considered in the analysis

The average standard length of Arctic cod post yolksac larvae increased slowly but steadily with time in 1988 (0.018 $\mathrm{mm} \mathrm{d}^{-1}$ ) (Fig. 9a). In 1989, the apparent growth rate $\left(0.019 \mathrm{~mm} \mathrm{~d}^{-1}\right)$ is based on only a few val-
SAND LANCE (Ammodytes sp.)

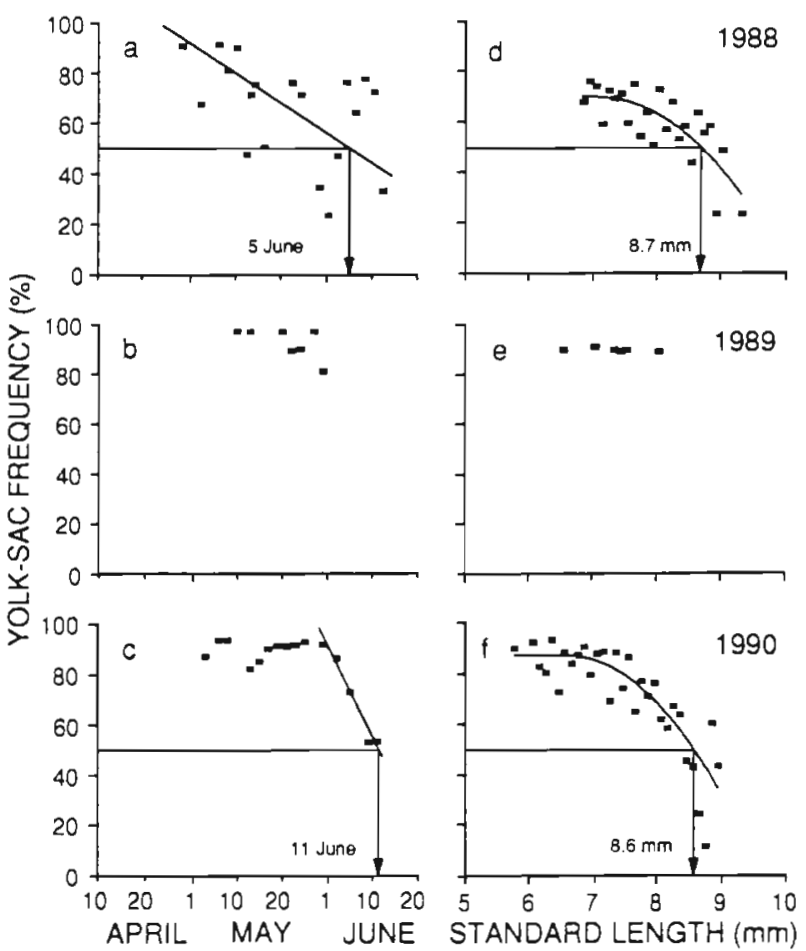

Fig. 8. Ammodytes sp. Yolk-sac frequency in sand lance larvae as a function of ( $a$ to $c$ ) date and ( $d$ to $f$ ) standard length by year. Only those data points representing at least 5 larvae were considered in the analysis

ues of length at date (Fig. 9b). In 1990, the length of Arctic cod post yolk-sac larvae decreased initially, and then increased rapidly (ca $0.15 \mathrm{~mm} \mathrm{~d}^{-1}$ ) from late May to mid June (Fig. 9c). In post yolk-sac sand lance lar-

Table 2. Boreogadus saida, Ammodytes sp. Interannual comparisons (paired $t$-test) of feeding incidence (percentage of larvae with prey) and mean feeding ratio (number of prey per gut) at length for Arctic cod and sand lance larvae. Larvae were classified in $0.1 \mathrm{~mm}$ length intervals

\begin{tabular}{|c|c|c|c|c|c|c|}
\hline & \multicolumn{3}{|c|}{ Feeding incidence $(\%)$} & \multicolumn{3}{|c|}{ Mean no. of prey } \\
\hline & $1988-89$ & $1989-90$ & $1988-90$ & $1988-89$ & $1989-90$ & $1988-90$ \\
\hline \multicolumn{7}{|l|}{ Arctic cod } \\
\hline Length range compared ( $\mathrm{mm}$ ) & $5.6-8.1$ & $5.6-8.1$ & $5.6-8.5$ & $5.6-8.1$ & $5.6-8.1$ & $5.6-8.5$ \\
\hline No. of intervals compared & 26 & 26 & 30 & 26 & 26 & 30 \\
\hline Mean values for years compared & $19 / 25$ & $25 / 86$ & $23 / 87$ & $0.44 / 0.75$ & $0.75 / 2.27$ & $0.54 / 2.43$ \\
\hline Mean difference between years & 6 & 60 & 64 & 0.31 & 1.52 & 1.89 \\
\hline$t$-statistic & 2.2 & 22.6 & 21.5 & 2.7 & 10.8 & 13.7 \\
\hline Probability of larger $t$ & 0.037 & $<0.001$ & $<0.001$ & 0.011 & $<0.001$ & $<0.0001$ \\
\hline \multicolumn{7}{|l|}{ Sand lance } \\
\hline Length range compared ( $\mathrm{mm}$ ) & $6.4-7.9$ & $6.3-7.9$ & $6.4-8.7$ & $6.4-7.9$ & $6.3-7.9$ & $6.4-8.7$ \\
\hline No. of intervals compared & 15 & 16 & 23 & 15 & 16 & 23 \\
\hline Mean values for years compared & $10 / 12$ & $11 / 28$ & $13 / 29$ & $0.14 / 0.16$ & $0.15 / 0.38$ & $0.18 / 0.40$ \\
\hline Mean difference between years & 2 & 17 & 15 & 0.02 & 0.23 & 0.22 \\
\hline$t$-statistic & 0.5 & 5.1 & 5.7 & 0.6 & 4.6 & 5.4 \\
\hline Probability of larger $t$ & 0.623 & $<0.001$ & $<0.001$ & 0.559 & $<0.001$ & $<0.001$ \\
\hline
\end{tabular}




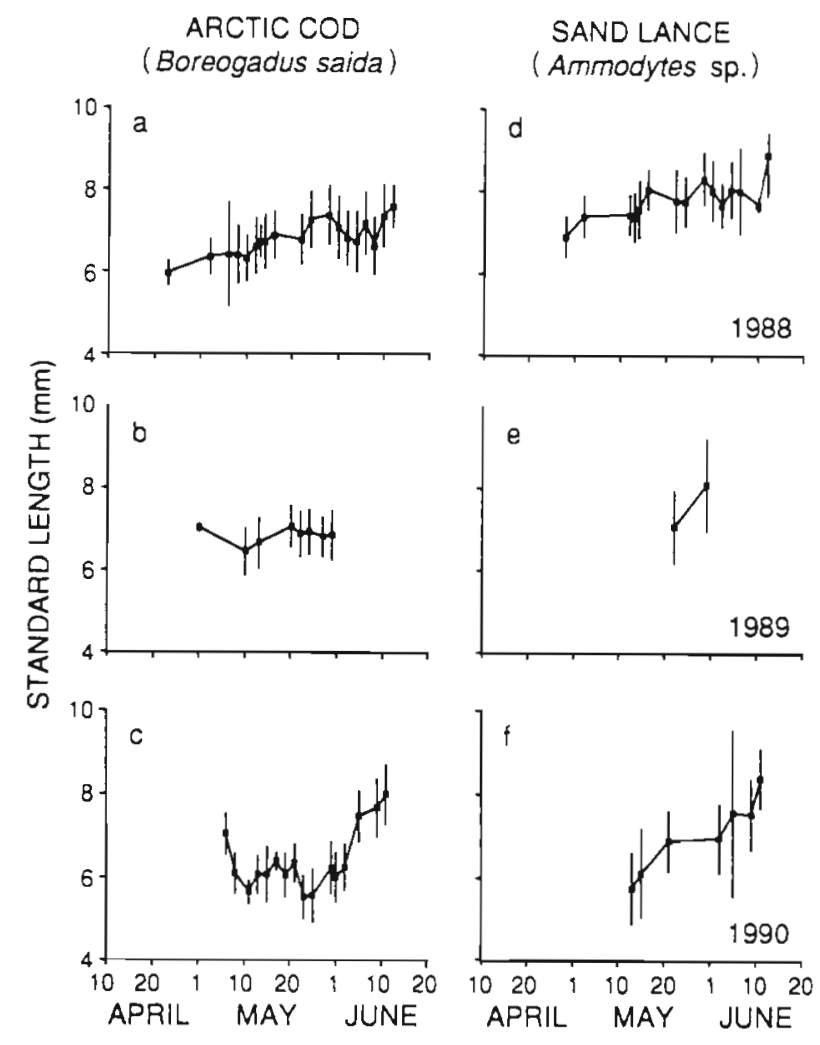

Fig. 9. Boreogadus saida, Ammodytes sp. Average length $( \pm 1$ standard deviation) at date of (a to c) Arctic cod and ( $d$ to $f$ ) sand lance larvae by year Only those data points representing at least 5 larvae are plotted

vae, the average rate of increase in length in 1988 $\left(0.025 \mathrm{~mm} \mathrm{~d}^{-1}\right)$ was one-third that of $1990(0.077 \mathrm{~mm}$ $\mathrm{d}^{-1}$ ) (Fig. 9d, f). Too few data were available to characterize the apparent growth of post yolk-sac sand lance in 1989 (Fig. 9e).

\section{Interannual differences in feeding success}

Dramatic differences were observed among years in the feeding success of Arctic cod larvae. At a given length, feeding incidence (percentage of larvae with at least one prey in gut) and feeding ratio (the average number of prey per larva) were minimum in 1988, intermediate in 1989 and maximum in 1990 (Fig. 10). For larvae of 5.6 to $8.5 \mathrm{~mm}$, feeding incidence and feeding ratio increased on average by about 4 -fold between extreme years, from $23 \%$ and 0.54 prey respectively in 1988 to $87 \%$ and 2.4 prey in 1990 (Table 2). In 1989 , the situation was somewhat intermediate between the failure of 1988 and the success of 1990 . Relative to 1988 , feeding incidence in larvae 5.6 to $8.1 \mathrm{~mm}$ increased from 19 to $25 \%$ and feeding ratio from 0.44 to 0.75 prey (Table 2). The observed differences
ARCTIC COD (Boreogadus saida)

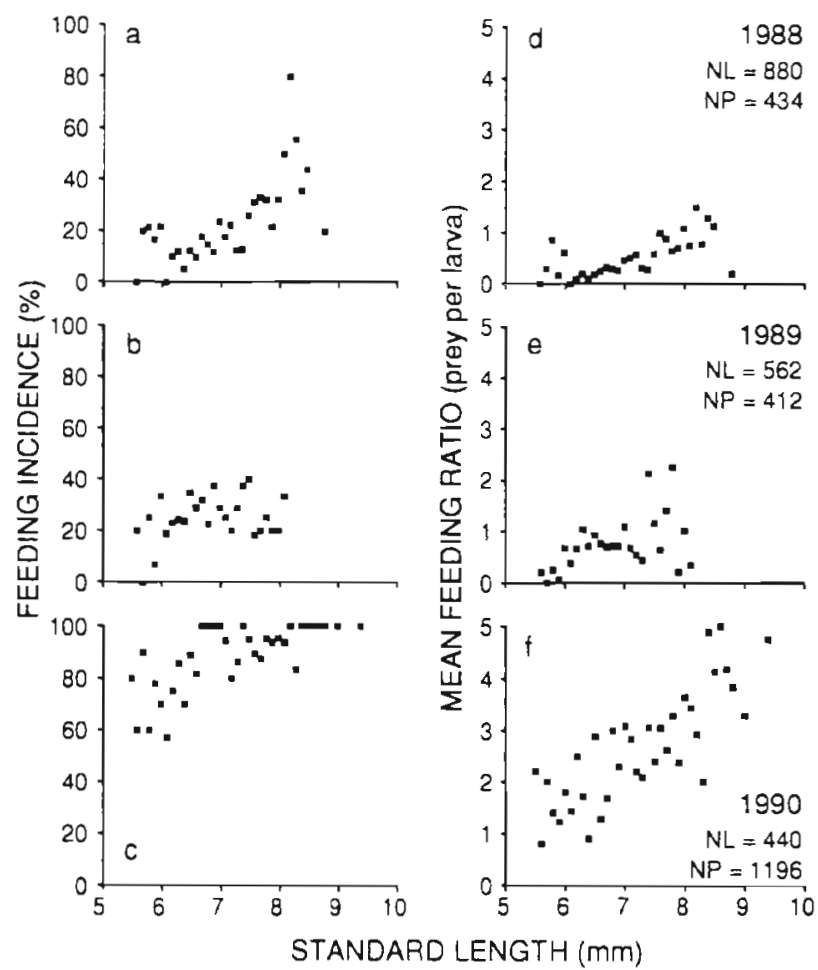

Fig. 10. Boreogadus saida. Feeding incidence (percentage of larvae with prey) and feeding ratio (mean number of prey per larva) of Arctic cod larvae as a function of standard length, by year. Data grouped by length-intervals of $0.1 \mathrm{~mm}$. Only those length-intervals including at least 5 larvae are plotted. The overall number of larvae (NL) and prey (NP) are given

between pairs of years were highly significant (Table 2).

Comparable results were obtained when feeding success was plotted against the percentage of post yolk-sac larvae in the population (Fig. 11). Feeding incidence when $50 \%$ of the larvae had exhausted their yolk was 0,30 and $>75 \%$ in 1988, 1989 and 1990 respectively (Fig 11a to c). Conversely, 50\% feeding occurred when $>90$, ca 70 , and $<40 \%$ of the larvae had exhausted their yolk in 1988, 1989, 1990 respectively. Comparing these values of yolk-sac frequency at $50 \%$ feeding incidence with yolk-sac frequency at date (Fig. 7 a to $\mathrm{c}$ ), indicates that $50 \%$ feeding occurred $3 \mathrm{wk}$ after yolk-sac resorption in 1988, ca 1 wk after it in 1989 , and $>1$ wk before it in 1990. Similar interannual differences were observed in the relationship between the number of prey ingested and the percentage of post yolk-sac larvae (Fig. 11d to f).

The feeding success of sand lance larvae was better in 1990 than in 1988 and 1989, but interannual differences were generally less striking than in Arctic cod (Figs. $12 \& 13$ ). Feeding success was low (Figs. 12 \& 13) 


\section{ARCTIC COD (Boreogadus saida)}

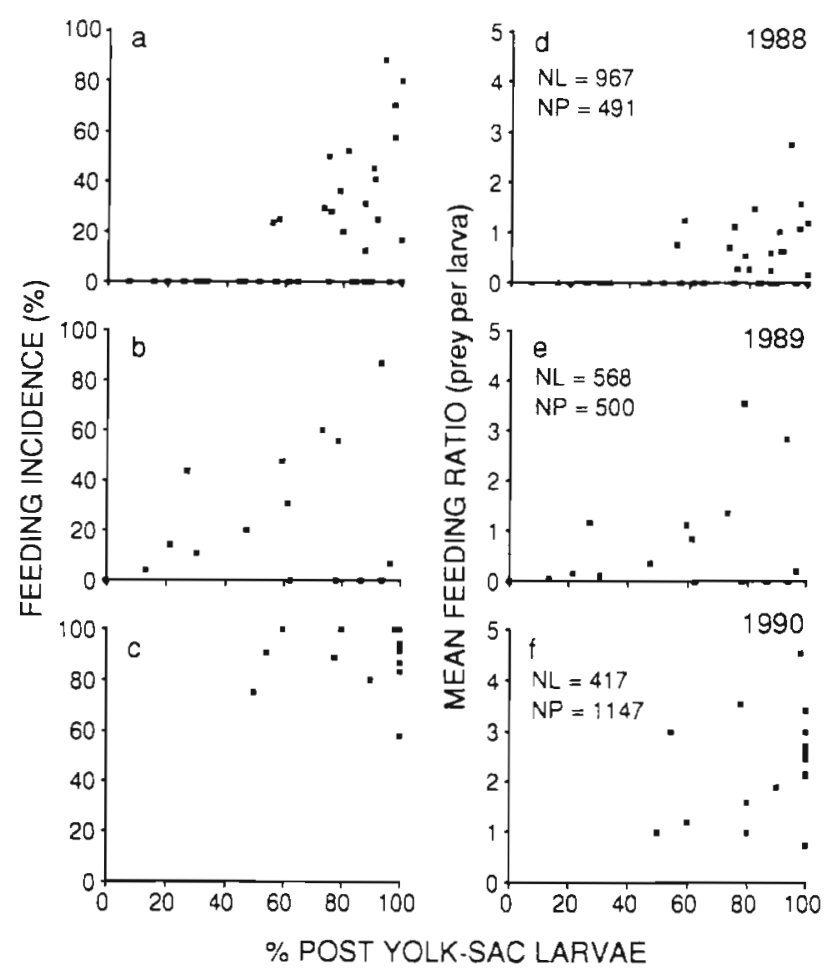

Fig. 11. Boreogadus saida. Feeding incidence (percentage of larvae with prey) and feeding ratio (mean number of prey per larva) of Arctic cod larvae as a function of the percentage of post yolk-sac larvae in the sample, by year. The overall number of larvae (NL) and prey (NP) are given

and not significantly different in 1988 and 1989 (Table 2). In 1990, feeding incidence and feeding ratio were on average about twice those of 1988 or 1989 . For example, feeding incidence and feeding ratio in sand lance 6.4 to $8.7 \mathrm{~mm}$ were $13 \%$ and 0.18 prey respectively in 1988 in comparison to $29 \%$ and 0.40 prey in 1990

Feeding incidence and feeding ratio in Arctic cod and sand lance larvae were independent of sampling depth and sampling hour (Fortier et al. in press).

\section{DISCUSSION}

\section{Early and synchronous strategists in subarctic ecosystems}

A first assumption of the match/mismatch hypothesis is that the spawning strategies of fish have evolved so as to synchronize the annual production of the larvae with maximum annual availability of their prey. In subarctic coastal ecosystems, 2 distinct reproduction strategies have been observed in relation to the avail- ability of larval fish prey. 'Synchronous' strategists (sensu Sherman et al. 1984) produce larvae that start feeding during peak abundance of copepod nauplii in late spring. Synchronous strategists include stichaeids and cottids in Hudson Bay (Drolet et al. 1991. Ponton et al. 1993) and osmerids, walleye pollock Theragra chalcogramma and flathead sole Hippoglossoides elassodon in Auke Bay, southeast Alaska (Haldorson et al. 1989, 1993). In contrast, 'early' strategists produce larvae that initiate feeding several weeks or even months before the phytoplankton bloom and the maximum abundance of potential prey. Early strategists include Arctic cod and sand lance in Hudson Bay (Drolet et al. 1991, Ponton et al. 1993, this study) and Pacific sand lance Ammodytes hexapterus and rock sole Pleuronectes bilineatus in Auke Bay (Haldorson et al. 1989, 1993). A similar dichotomy between synchronous and early strategists has been reported for temperate coastal waters (e.g. Bollens et al. 1992).

Bollens et al. (1992) suggested that the early strategy of some species in Dabob Bay (Washington, USA) is dictated by the need to avoid predators during early development or to synchronize metamorphosis with

SAND LANCE (Ammodytes sp.)

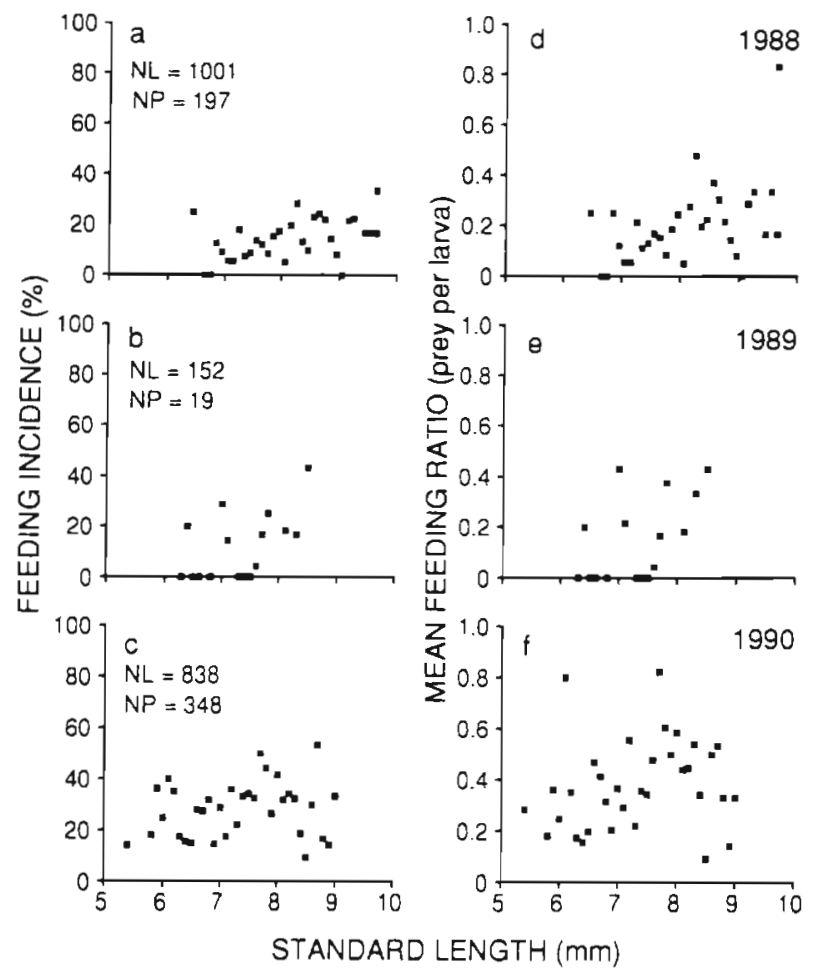

Fig. 12. Ammodytes sp. Feeding incidence (percentage of larvae with prey) and feeding ratio (mean number of prey per larva) of sand lance larvae as a function of standard length, by year. Data grouped by length-intervals of $0.1 \mathrm{~mm}$. Only those length-intervals including at least 5 larvae are plotted. The overall number of larvae (NL) and prey (NP) are given 
SAND LANCE (Ammodytes sp.)

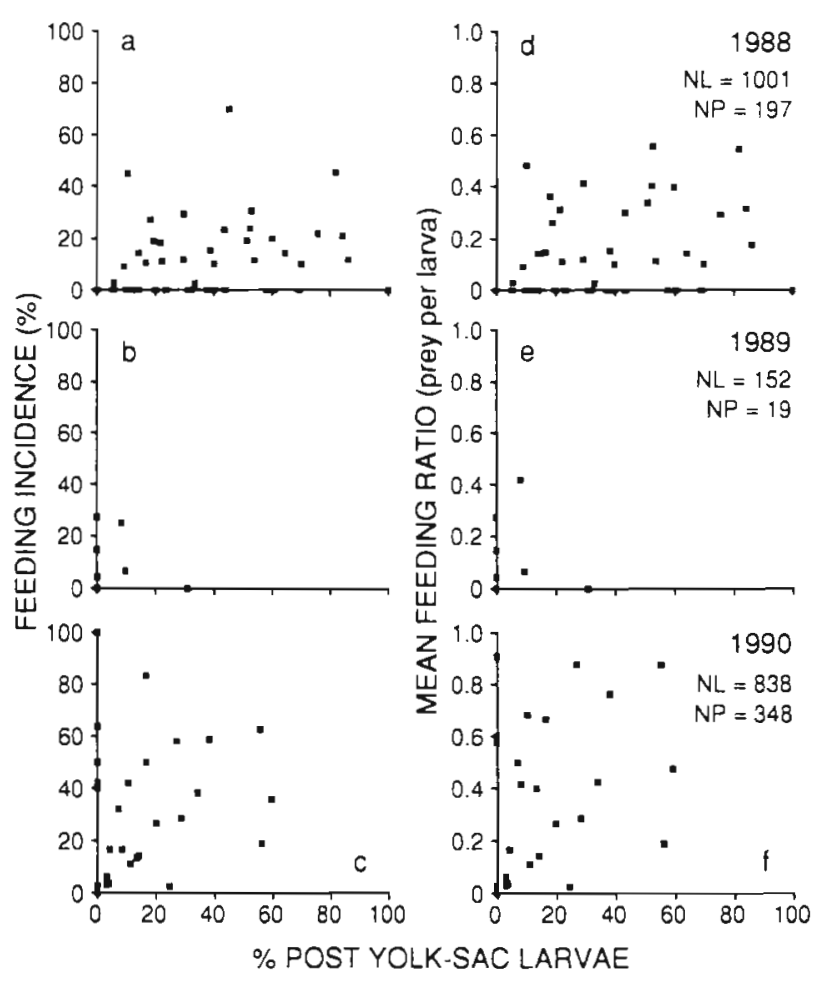

Fig. 13. Ammodytes sp. Feeding incidence (percentage of larvae with prey) and feeding ratio (mean number of prey per larva) of sand lance larvae as a function of the percentage of post yolk-sac larvae in the sample, by year. The averall number of larvae (NL) and prey (NP) are given

peak abundance of zooplankton prey in summer. Few potential predators of fish larvae are found in spring under the ice cover of Hudson Bay (Ponton \& Fortier 1992), in contrast with the summer months which are characterized by swarms of medusae and other gelatinous plankton (D. Ponton pers. obs.). Thus, avoidance of soft-bodied zooplankton, which are among the most important predators of fish larvae (e.g. Purcell 1990), could be the constraint driving Arctic cod and sand lance to spawn early. Drolet et al. (1991) noted that early species in Hudson Bay produced smaller larvae with poorer foraging abilities than synchronous species. Hatching early may allow the small larvae of early strategists to maximize growth before the incoming winter.

Bollens et al. (1992) argued that the delay between the reproduction of early species and peak reproduction of copepods in summer is evidence that a match or mismatch of the early larvae with their prey is of secondary importance in determining the spawning strategy of these species. Others have noted as well that compliance to higher order constraints (e.g. avoiding predation on the small larvae, insuring optimal feeding conditions at metamorphosis, or preserving the cohesion of the larval population) may force the production of larvae, in some species, to occur within periods or regions where poor feeding conditions prevail (Iles \& Sinclair 1982, Sinclair \& Tremblay 1984, Economou 1987, Sinclair 1988, Fortier \& Gagné 1990). Yet, precisely because of this incidental selection of unfavourable initial feeding conditions in response to higher constraints, it can be expected that interannual variations in prey availability to post yolk-sac larvae will play an important role in the determination of year class strength in these species (Fortier \& Gagné 1990). Contrary to Bollens et al. (1992), we believe that the larvae of early strategists (rather than the metamorphosing fish) should be particularly vulnerable to a mismatch with their scarce - and therefore potentially limiting - prey. This view is consistent with the results of a recent simulation of the growth and death of haddock larvae (Melanogrammus aeglefinus), in which recruitment to metamorphosis depended strongly on a match with prey during the larval period (Cushing \& Horwood 1994).

\section{Potential for a mismatch between fish larvae and their prey in subarctic regions}

A second and central assumption of the match/mismatch hypothesis is that the production of fish larvae (whether early or synchronous) is seasonally fixed while the timing and intensity of prey production may vary substantially between years. In the present study, the timing of yolk-sac resorption in Arctic cod and sand lance varied by less than 1 wh between years. The abundance of copepod nauplii (the primary prey) under the ice cover varied widely both in magnitude ( 7 -fold) and in timing ( 4 to $6 \mathrm{wk}$ ). In the Norwegian Sea, the date of $50 \%$ spawning in Atlantic cod Gadus morhua ranged from 28 March to 4 April over 1976 to 1986, while the timing of the production of Calanus finmarchicus nauplii, the main prey of the larvae, varied by up to $6 \mathrm{wk}$ (Ellertsen et al. 1989). Paul et al. (1991) reported considerable interannual variation in the availability of copepod nauplii in the size range 150 to $350 \mu \mathrm{m}$ from 1986 to 1989 in Auke Bay (SE Alaska, USA), while the different species of fish larvae in the bay tended to occur at the same time every year (Haldorson et al. 1989, 1993). Consistent with this second assumption of the match/mismatch hypothesis, the timing of larval fish production appears remarkably constant from year to year in subarctic coastal ecosystems, whereas significant variations in the timing and level of prey availability are observed. Thus, the potential exists at these latitudes for interannual variations in the degree of coincidence between fish larvae and their food. 
Which of the early and synchronous strategies makes the larvae of subarctic fish potentially more vulnerable to a mismatch with their prey is debated. In southeastern Hudson Bay, Drolet et al. (1991) observed that feeding conditions under the ice cover were poor in 1988 and that the physiological condition of early species deteriorated substantially after yolk resorption. There was no evidence of emaciation in the post yolksac larvae of synchronous species that hatched during peak abundance of prey after the ice break-up. Drolet et al. (1991) concluded that the small larvae of early species should be more vulnerable to a potential mismatch than the large larvae of synchronous species. The results of the present study confirm that the feeding of 'early' larvae under the ice cover of Hudson Bay may be severely limited in some years and much less so in others.

Haldorson et al. (1993) pointed out that, because they experience higher temperatures (which mean higher metabolic costs) and higher predator abundances, the larvae of synchronous species may nevertheless be sensitive to a mismatch with their relatively abundant prey. In the Norwegian Sea, temperaturemediated variations in the timing of the reproduction of Calanus finmarchicus led to a mismatch between Atlantic cod larvae and their nauplii prey in extreme cold and warm years and a match in years with normal temperatures (Ellertsen et al. 1989). The dependence of recruitment on environmental temperature supports the hypothesis that a temperature-mediated match/ mismatch mechanism determines, at least in part, the strength of year classes in synchronous Atlantic cod (Ellertsen et al. 1989). Yet, Paul et al. (1991) and McGurk et al. (1993) concluded that synchronous strategists were unlikely to be vulnerable to a mismatch between larvae and prey, because they often produce several distinct cohorts of larvae. These authors concluded that, in any year, at least one of these cohorts will encounter nauplii concentrations high enough to guarantee survival in Auke Bay. This is supported by recent studies of the hatching date frequency distribution of synchronous species linking differences in the survival of distinct cohorts to the availability of prey organisms at the time of hatching (Nakatani 1991, Fossum \& Moksness 1993). Thus, multiple spawning may reduce the risk that a given year class be virtually eradicated by a mismatch between larvae and prey. Yet, the strength of a year class is made up of the sum of the survivals of all cohorts (den Boer 1968, Fortier \& Leggett 1985). If, in a given year, several cohorts encounter suitable feeding and growth conditions, the year class may be expected to be stronger on average than if only 1 cohort experiences high survival (according to the match/mismatch hypothesis). Thus, the possibility remains that year class strength will be affected by a match/mismatch mechanism even in synchronous species that have evolved multiple spawning (the bet-hedging strategy; Lambert 1984, Lambert \& Ware 1984) or the production of relatively large larvae at hatching (Haldorson et al. 1989, Drolet et al. 1991) to attenuate the potential impact of poor feeding conditions in the plankton.

\section{Subarctic microalgal blooms and the availability of larval fish prey}

A third (and somewhat peripheral) assumption of the match/mismatch hypothesis is that interannual variations in the production of larval fish prey are rooted in variations in the timing of the spring (or autumn) algal bloom. Our results do not support this assumption for southeastern Hudson Bay in spring. Interannual variations in the density of copepod nauplii under the ice cover appeared unrelated to variations in the bloom of either ice-algae or phytoplankton. The abundance of nauplii (mostly cyclopoid nauplii based on the prosome width frequency distribution) depended essentially on the number of females of small copepods (such as Oithona similis and Oncaea borealis). Likewise, Paul et al. (1990) showed that the abundance of females rather than the availability of algal biomass explained interannual differences in the production of Pseudocalanus spp. nauplii, the main prey of first-feeding fish larvae in Auke Bay. The conditions governing the number of female copepods under the ice of Hudson Bay are poorly understood but we suspect that the production of copepodites in the previous summer and fall, and their survival in winter are important factors.

For southeastern Hudson Bay, Runge et al. (1991) proposed that the grazing of ice algae released from the ice-water interface in April and May accelerates oogenesis and allows female Calanus glacialis (and perhaps female Pseudocalanus spp.) to reach maximum egg production at the time of the phytoplankton bloom which follows the break-up of the ice cover in early June. Assuming that yolk resorption took place in early June, these authors hypothesized that the onset of first feeding in Arctic cod and sand lance larvae was synchronized with this increased production of $C$. glacialis and Pseudocalanus spp. nauplii in June. Although admittedly based on a single year of observation (1986), this led Runge et al. (1991) to hypothesize a strong coupling (sensu Runge 1988) between ice algal production and the first feeding of Arctic cod and sand lance larvae. Drolet et al. (1991) confirmed that, in 1988, intense feeding by Arctic cod and sand lance larvae did not begin until the increase in the abundance of copepod nauplii in June. Yet, our results for 1990 clearly indicate that sufficient numbers of nauplii 
to ensure high feeding incidence ( $>80 \%$ in Arctic cod) can be produced several weeks before the ice breakup in some years. Based on the size of the nauplii eaten, Arctic cod and sand lance larvae fed primarily on the nauplii of small copepods such as the numerically dominant Oithona similis and Oncaea borealis. We suggest that the early production of Arctic cod and sand lance larvae in Hudson Bay is a strategy to synchronize first feeding with this potential (but not always realized) early production of small cyclopoid nauplii, rather than with the phytoplankton bloom and the increased production of calanoid nauplii that follows the ice break-up.

As mentioned above, interannual differences in the timing and abundance of cyclopoid nauplii under the ice were not linked to the timing or intensity of the ice algal bloom. Thus, contrary to Runge et al. (1991), we conclude that, at least in the area of coastal southeastern Hudson Bay influenced by river runoff, the coupling between ice algal blooms and the first feeding of larval Arctic cod and sand lance is weak (sensu Runge 1988). Interestingly, this is consistent with the prediction that this coupling should be weak when mediated by small copepods such as Oithona, Oncaea and Pseudocalanus, the reproduction of which is less sensitive to the availability of microalgal biomass than to other factors such as population structure and predation (Runge 1988). Whether such a weak coupling prevails farther offshore in Hudson Bay, where the detrimental effect of river inputs on ice algal biomass (e.g. Legendre et al. 1992) is presumably less, remains to be ascertained. Also, given the clear link between ice algae and the later reproduction of calanoid copepods at or after the ice break-up (Runge et al. 1991), this coupling may be stronger in the case of synchronous fish species, which occur at or after the ice break-up, than in the case of early species such as Arctic cod and sand lance.

\section{Interannual variations in larval fish feeding rates and growth}

A first prediction of the match/mismatch hypothesis is that, in years of mismatch, prey availability will limit the feeding success of the planktonic larval stages. The ultimate test of this prediction requires that both prey availability and the feeding success of the larvae (feeding incidence or feeding ratio at length) be measured and compared on an interannual basis. While some attention has been given to interannual variations in prey density in subarctic environments (see above), surprisingly few studies have looked at interannual variations in the actual feeding success of the young fish at these and other latitudes. For example, claims that the larvae of synchronous species are never food limited because they occur during maximum availability of their prey (e.g. Paul et al. 1991. McGurk et al. 1993) have not been substantiated by gut content analyses. In temperate waters, higher survival and robustness of Atlantic herring larvae Clupea harengus on Georges Bank-Nantucket Shoals in 1976 relative to 1974 and 1975 was attributed to higher feeding incidence (Cohen \& Lough 1983). Year class strength of American shad Alosa sapidissima was directly related to larval feeding success which, in turn, was proportional to zooplankton density in the Connecticut River, NE USA (Crecco \& Savoy 1984). Off the coast of Oregon, USA, higher frequency of empty guts in English sole larvae Parophrys vetulus in 1971 (30 to 100\%) relative to 1973 (10 to $60 \%$ ) was due to a mismatch in 1971 between the larvae and appendicularians, their main prey (Gadomski \& Boehlert 1984). In Storm Bay (eastern Tasmania), the average feeding ratio of larval jack mackerel Trachurus declivis was nearly 6 times higher in 1988 (7.17 prey per gut) than in 1989 (1.25), but it was not possible to relate the difference to prey availability because the $500 \mu \mathrm{m}$ mesh used did not retain the prey of the larvae (Young \& Davis 1992). Spatially, the feeding ratio at length of small (5.1 to $5.9 \mathrm{~mm}$ ) walleye pollock larvae in Shelikof Strait (Gulf of Alaska) was higher inside a patch of larvae in which higher densities of nauplij were found relative to surrounding waters (Canino et al. 1991).

In the present study, the interannual comparison of larval production in relation to prey availability indicates that 1988 and seemingly 1986 (based on the data presented by Runge et al. 1991) were years of mismatch between the immutable production of Arctic cod and sand lance larvae in mid May and the delayed and low availability of their nauplii prey in these 2 years. Results for 1990 clearly indicate that, in some years, the early availability of suitable numbers of copepod nauplii can ensure a match between the production of the larvae and that of their prey under the ice cover of Hudson Bay. For both species, the match of 1990 resulted in a remarkable improvement of feeding success relative to the mismatch of 1988 . Feeding incidence and feeding ratio increased by about 4 -fold in Arctic cod larvae 5.6 to $8.5 \mathrm{~mm}$ and by over 2 -fold in sand lance 6.4 to $8.7 \mathrm{~mm}$. At the level of the population, $50 \%$ feeding in Arctic cod started 3 wk after yolk-sac resorption in 1988, but at least $1 \mathrm{wk}$ before in 1990 . Thus, feeding started not only 1 mo earlier in 1990 than in 1988, but also at an earlier developmental stage. The situation in 1989 was somewhat closer to the mismatch of 1988 than to the match of 1990: the feeding success of Arctic cod larvae was significantly improved relative to 1988 but not that of sand lance. 
Fortier et al. (in press) evidenced a close link, via the timing of the spring freshet, between climate and interannual variations in the feeding success of Arctic cod and sand lance larvae. This climatic forcing implies that the interannual variations in feeding conditions reported here prevail at least over the area of ice-covered Hudson Bay influenced by river plumes in spring, i.e. over most of the coastal zone (e.g. CSSA Consultants Ltée 1992). The overall impact, on the early survival of each species, of interannual variations in feeding conditions linked to variations in the timing of the freshet will depend on the fraction of the larval dispersal area that is affected by river plumes (Fortier et al. in press). The inshore-offshore extent of the larval distribution of Arctic cod and sand lance under the ice cover of Hudson Bay is unknown, and whether the fraction of the larval dispersion area that is affected by river plumes is significant or not remains to be assessed.

A second prediction of the match/mismatch hypothesis is that growth will be reduced in years of mismatch. Although temperature is often the main determinant of larval fish growth (see Houde 1989 for a review), several field studies have linked spatial (Buckley \& Lough 1987, Karakiri et al. 1989, Suthers et al. 1989), seasonal (Crecco \& Savoy 1985, Hovenkamp 1990) and interannual (Haldorson et al. 1989, Karakiri et al. 1989) variations in growth to prey density. Other studies found no link between interannual variations in growth rate and prey abundance (Butler 1989, McGurk et al. 1992).

Field studies linking interannual variations in growth to differences in the actual feeding success of the larvae are scant. Around Rockall Bank (west of Scotland), the gut content of blue whiting larvae Micromesistius poutassou of all sizes in the interval 3 to $42 \mathrm{~mm}$ was heavier in 1968 than in 1967 and this may have led to higher growth rates in 1968 (Conway 1980). Recent studies in Shelikof Strait (Gulf of Alaska) clearly link interannual variations in the growth of walleye pollock larvae Theragra chalcogramma to feeding success as measured by feeding ratio at length (Bailey et al. 1995). Spatially, differences in the individual growth rate of larval southern bluefin tuna Thunnus maccoyii in the East Indian Ocean were positively correlated to feeding rate (Jenkins et al. 1991). In the present study, actual growth based on age determination is not available but estimates of apparent growth (from length at date of the post yolk-sac larvaej are generally consistent with the prediction that growth rates should be higher in years of match than in years of mismatch. The increase in length of sand lance post yolk-sac larvae was steeper in 1990 (match year) than in 1988 (mismatch year). In Arctic cod, the length of post yolk-sac larvae remained constant initially in 1990, but then increased at a much faster rate than in 1988 or 1989.
A third prediction of the match/mismatch hypothesis is that feeding success and early growth determine year class strength. Crecco \& Savoy's study (1984) linking year class strength of American shad to larval feeding success in the Connecticut River represents perhaps the best attempt so far at testing this central prediction of fisheries research. Ellertsen et al. (1989) have measured neither larval feeding success nor growth but have nevertheless established a convincing link between a match/mismatch mechanism and year class strength in Atlantic cod in the Norwegian Sea. In the present study, whether the improved feeding success and growth of Arctic cod and sand lance larvae led to a stronger year class in 1990 than in 1988 or 1989 will never be known since there are no commercial fisheries for the 2 species in Hudson Bay and, therefore, no estimate of recruitment.

\section{The match/mismatch hypothesis}

The match/mismatch hypothesis is perhaps still considered the extant hypothesis accounting for the control of population numbers of marine fish' (Sinclair 1988 , p. 24). In recent reviews, the results of the very same studies have been interpreted as either non-supportive (Sinclair 1988) or supportive (Cushing 1990) of the hypothesis. This paradox may reflect the difficulty of designing studies that actually verify its assumptions and predictions. By its very nature, the match/mismatch hypothesis is difficult to test (Cushing 1990).

In the present study we evaluated some of the assumptions and predictions of the match/mismatch hypothesis for the larvae of early strategists in a subarctic sea. While some peripheral postulates of the hypothesis appeared unjustified for the environment under study, the central assumptions and predictions proved relatively resistant to our tests. Contrary to the first assumption of the match/mismatch, early strategists such as Arctic cod and sand lance in Hudson Bay hatch several weeks before the maximum availability of their prey. If anything, this lack of synchronism makes the larvae of early strategists even more vulnerable to a mismatch, because of the low abundance of copepod nauplii under the ice and the inferior feeding conditions that generally prevail before the massive reproduction of calanoid copepods in summer. The assumption of an annually fixed production of larvae and a variable production of prey was supported. Yet no link was found between the timing or level of prey availability and the timing of microalgal production. Although the long-term yield in fish of an oceanographic system clearly depends on its primary productivity (Iverson 1990), our results suggest that, on an annual basis, fluctuations in the feeding success and 
survival of fish larvae in subarctic Hudson Bay are not necessarily strongly linked to fluctuations in the annual cycle of primary production. A lack of universal dependence of copepod reproduction on algal blooms may remove some of the elegance of the match/mismatch hypothesis (Sinclair \& Tremblay 1984, Sinclair 1988) but, in our opinion, little of its heuristic value in understanding recruitment variability in fish.

The prediction of reduced feeding success and growth in years of mismatch was supported by our results. However, in addition to prey density, other factors not considered by the match/mismatch hypothesis, such as light (Gilbert et al. 1992, Ponton \& Fortier 1992, Fortier et al. in press), turbulence (Sundby \& Fossum 1990) or competence of larvae (McGurk et al. 1993), may contribute to determine feeding success in fish larvae. Thus, feeding incidence and feeding ratio will always be preferable to prey density as indices of the actual energy intake by the larvae. Despite the central role of feeding success in the present paradigm on recruitment determination, surprisingly few studies have tried to relate year class strength to feeding incidence, feeding ratios and growth rates during the early planktonic life of fish. Although costly and time-consuming, analyses of gut content and otoliths enable us to assess feeding success and growth with some precision. If larval feeding success and growth are indeed the determinants of recruitment, these are the proximal indices (rather than prey density and larval numbers) that need to be correlated with year class strength in order to verify or falsify current hypotheses on the role of energetics in recruitment determination.

Acknowledgements. This study was part of a collaborative project between GIROQ and the Department of Fisheries and Oceans Canada (DFO - Institut Maurice-Lamontagne). Field and laboratory work was funded by NSERC, DFO and Employment and Immigration Canada grants to L.F., and by NSERC and Fonds FCAR du Québec grants to GIROQ. Helicopter time was provided by DFO. The Centre d'études nordiques (Université Laval) provided accommodation at its field station in Kuujjuarapik. Special thanks to R. Drolet for his contribution to this study. G. Bergeron, M. Bolduc, $C$. Dutil, M. Frenette, A. Gagné, L. Girard, N. Hamel, R. Labbé, L. Michaud, D. Morissette, M. Parent, J. Ponton, M.-A. Rémillard, J.-G. Rondeau, M. Salathé, S. Tourangeau and J. Vaillancourt assisted in the field or the laboratory. D. Cushing, J. Runge, H. Browman, J. M. Napp and an anonymous referee provided constructive comments on an earlier version of the manuscript.

\section{LITERATURE CITED}

Anderson, J. T (1988) A review of size dependent survival during pre-recruit stages of fishes in relation to recruitment. J. Northw. Atl. Fish. Sci. 8: 55-66

Bailey, K. M., Canino, M. F., Napp, J. M., Spring, S. M., Brown, A. L. (1995). Two contrasting years of prey levels, feeding condition and mortality of larval walleye pollock (Theragra chalcogramma) in the western Gulf of Alaska. Mar. Ecol. Prog. Ser. 119: 11-23

Bollens, S. M., Frost, B. W., Schwaninger, H. R., Davis, C. S. Way, K. J., Landsteiner, M. C. (1992). Seasonal plankton cycles in a temperate fjord and comments on the matchmismatch hypothesis. J. Plankton Res. 14: 1279-1305

Buckley, L. J., Lough, R. G. (1987). Recent growth, biochemical composition, and prey field of larval haddock (Melanogrammus aeglefinus) and Atlantic cod (Gadus morhua) on Georges Bank. Can. J. Fish. Aquat. Sci. 44: $14-25$

Butler, J. L. (1989). Growth during the larval and juvenile stages of the northern Anchovy, Engraulis mordax, in the California current during 1980-84. Fish. Bull. U.S. 87 . $645-652$

Canino, M. F., Bailey, K. M., Incze, L. S. (1991). Temporal and geographic differences in feeding and nutritional condition of walleye pollock larvae Theragra chalcogramma in Shelikof Strait, Gulf of Alaska. Mar. Ecol. Prog. Ser. 79 : $27-35$

Cohen, R. E., Lough, R. G. (1983). Prey field of larval herring Clupea harengus on a continental shelf spawning area. Mar. Ecol. Prog. Ser. 10: 211-222

Conway, D. V. P. (1980). The food of larval blue whiting, Micromesistius poutassou (Risso), in the Rockall area. J. Fish. Biol. 16: 709-723

Crecco, V. A., Savoy, T F. (1984). Effects of fluctuations in hydrographic conditions on year-class strength of American shad (Alosa sapidissima) in the Connecticut River. Can. J. Fish. Aquat. Sci. 41. 1216-1223

Crecco, V. A., Savoy, T. F. (1985). Effects of biotic and abiotic factors on growth and relative survival of young American shad, Alosa sapidissima, in the Connecticut River. Can. J. Fish. Aquat. Sci. 42: 1640-1648

CSSA Consultants Ltée (1992). Analyses objectives et descriptives de huit panaches d'eau saumâtre sous couverture de glace. Report presented to Hydro-Québec, Montreal

Cushing, D. H. (1974). The natural regulation of populations. In: Harden Jones F. R. (ed.) Sea fisheries research. Elek Science, London, p. 399-412

Cushing, D. H. (1975). Marine ecology and fisheries. Cambridge University Press, New York

Cushing, D. H. (1990). Plankton production and year-class strength in fish populations: an update of the match/mismatch hypothesis. Adv mar. Biol. 26: 249-293

Cushing, D. H., Harris, J. G. K. (1973). Stock and recruitment and the problem of density dependence. Rapp. P.-v. Réun. Cons. int. Explor. Mer 164: 142-155

Cushing, D. H., Horwood, J. W. (1994). The growth and death of fish larvae. J. Plankton Res. 16: 291-300

den Boer, P. J. (1968). Spreading of risk and stabilization of animal numbers. Acta Biotheor. 18: 165-194

Drolet, R., Fortier, L., Ponton, D., Gilbert, M. (1991). The production of fish larvae and their food resource in subarctic southeastern Hudson Bay. Mar. Ecol. Prog. Ser. 77 : $105-118$

Economou, A. N. (1987). Ecology of survival in some gadoid larvae of the northern North Sea. Environ. Biol. Fish. 19: $241-260$

Ellertsen, B., Fossum, P., Solemdal, P., Sundby, S. (1989). Relation between temperature and survival of eggs and first-feeding larvae of northeast Arctic cod (Gadus morhua L.). Rapp. P.-v. Réun. Cons. int. Explor. Mer 191: 209-219

Fortier, L., Gagné, J. A. (1990). Larval herring (Clupea haren- 
gus) dispersion, growth, and survival in the St. Lawrence estuary: match/mismatch or membership/vagrancy? Can. J. Fish. Aquat. Sci. 47: 1898-1912

Fortier, L., Gilbert, M., Ponton, D., Ingram, R. G., Robineau, B., Legendre, L. (in press). Impact of freshwater on a subarctic coastal ecosystem under seasonal sea ice (southeastern Hudson Bay, Canada). III. Feeding success of marine fish larvae. J. mar. Syst

Fortier, L., Leggett, W. C. (1985). A drift study of larval fish survival. Mar. Ecol. Prog. Ser. 25: 2455-257

Fortier, L., Levasseur, M. E., Drolet, R., Therriault, J.-C. (1992). Export production and the distribution of fish larvae and their prey in a coastal jet frontal region. Mar. Ecol Prog. Ser. 85: 203-219

Fossum, P. Moksness, E. (1993). A study of spring- and autumn-spawned herring (Clupea harengus L.) larvae in the Norwegian Coastal Current during spring 1990. Fish. Oceanogr. 2: 73-81

Gadomski, D. M., Boehlert, G.W. (1984). Feeding ecology of pelagic larvae of English sole (Parophrys vetulus) and butter sole (Isopsetta isolepis) off the Oregon coast. Mar. Ecol. Prog. Ser. 20: 1-12

Gilbert, M., Fortier, L., Ponton, D., Drolet, R. (1992). Feeding ecology of marine fish larvae across the Great Whale River plume in seasonally ice-covered southeastern Hudson Bay. Mar. Ecol. Prog. Ser. 84: 19-30

Gosselin, M., Legendre, L., Demers, S., R. G. Ingram (1985) Responses of sea-ice microalgae to climatic and fortnightly tidal energy inputs (Manitounuk Sound, Hudson Bay). Can. J. Fish. Aquat. Sci. 42: 999-1006

Grainger, E. H. (1988). The influence of a river plume on the sea-ice meiofauna in southeastern Hudson Bay. Estuar. coast. Shelf Sci. 27: 131-141

Gran, H. H., Braarud, T (1935). A quantitative study of the phytoplankton in the Bay of Fundy and the Gulf of Maine. J. Biol. Bd Can. 1: 279-467

Haldorson, L., Paul, A. J., Sterritt, D., Watts, J. (1989). Annual and seasonal variation in growth of larval walleye pollock and flathead sole in a southeastern Alaskan Bay. Rapp. P.-v. Réun. Cons. int. Explor. Mer 191: 220-225

Haldorson, L., Pritchett, M., Sterritt, D., Watts, J. (1993). Abundance patterns of marine fish larvae during spring in a southeastern Alaskan Bay. Fish. Bull. U.S. 91: 36-44

Hirche, H.-J., Bohrer, R. N. (1987). Reproduction of the Arctic copepod Calanus glacialis in Fram Strait. Mar. Biol. 94 $11-17$

Hiort, J. (1914). Fluctuations in the great fisheries of northern Europe viewed in light of biological research. Rapp. P.-v. Réun. Cons. perm. int. Explor. Mer 20: 1-228

Hovenkamp, F. (1990). Growth differences in larval plaice Pleuronectes platessa in the Southern Bight of the North Sea as indicated by otolith increments and RNA/DNA ratios. Mar. Ecol. Prog. Ser. 58: 205-215

Houde, E. D. (1989). Comparative growth, mortality, and energetics of marine fish larvae: temperature and implied latitudinal effects. Fish. Bull. U.S. 87: 471-495

Iles, T. D., Sinclair, M. (1982). Atlantic herring: stock discreteness and abundance. Science 215: 627-633

Ingram, R. G., Larouche, P. (1987). Variability of an underice river plume in Hudson Bay. J geophys. Res. 92(C9): $9541-9547$

Iverson, R. L. (1990). Control of marine fish production. Limnol. Oceanogr. 35: 1593-1604

Jenkins, G. P., Young, J. W., Davis, T. L. O. (1991). Density dependence of larval growth of a marine fish, the southern bluefin tuna, Thunnus maccoyii. Can. J. Fish. Aquat. Sci. 48: $1358-1363$
Jones, R. (1973). Density dependent regulation of the numbers of cod and haddock. Rapp. P-v. Réun. Cons. int. Explor. Mer 164: 156-173

Karakiri, M., Berghahn, R., von Westernhagen, H. (1989) Growth differences in 0 -group plaice Pleuronectes platessa as revealed by otolith microstructure analysis. Mar. Ecol. Prog. Ser. 55: 15-22

Kiørboe, T (1991). Pelagic fisheries and spatio-temporal variability in zooplankton productivity. In: Uye, S., Nishida, S. Ho, J.-S. (eds.) Proc. Fourth Int. Conf. Copepoda. Bull. Plankton Soc. Japan, Spec. Vol.: 229-249

Lambert, T (1984). Larval cohort succession in herring (Clupea harengus) and capelin (Mallotus villosus). Can. J. Fish. Aquat. Sci. 41: 1552-1564

Lambert, T., Ware, D. M. (1984). Reproductive strategies of demersal and pelagic spawning fish. Can. J. Fish. Aquat. Sci. 41: 1565-1569

Legendre, L., Martineau, M.-J., Therriault, J.-C., Demers, S. (1992). Chlorophyll a biomass and growth of sea-ice microalgae along a salinity gradient (southeastern Hudson Bay, Canadian Arctic). Polar Biol. 12: 445-453

Lepage, S., Ingram, R. G. (1991). Variation of upper layer dynamics during breakup of the seasonal ice cover in Hudson Bay. J. geophys. Res. 96(C7): 12711-12724

Lovegrove, T. (1956). Copepod nauplii (II). Cons. Int. Explor. Mer, Zooplankton Sheet 63

McGurk, M. D., Paul, A. J., Coyle, K. O., Ziemann, D. A., Haldorson, L. J. (1993) Relationships between prey concentration and growth, condition, and mortality of Pacific herring, Clupea pallasi, larvae in an Alaskan subarctic embayment. Can. J. Fish. Aquat. Sci. 50: 163-180

McGurk, M. D., Warburton, H. D., Galbraith, M., Kusser, W. C. (1992). RNA-DNA ratio of herring and sand lance larvae from Port Moller, Alaska: comparison with prey concentration and temperature. Fish. Oceanogr. 1: 193-207

Michel, C., Legendre, L., Therriault, J.-C., Demers, S., Vandevelde, T. (1993). Springtime coupling between ice algal and phytoplankton assemblages in southeastern Hudson Bay, Canadian Arctic. Polar Biol. 13: 441-449

Nakatani, T. (1991). Copepod nauplii as food of walleye pollock larvae (Pisces: Gadidae) in Funka Bay, Japan. In: Uye, S., Nishida, S., Ho, J.-S. (eds.) Proc. Fourth Int. Conf. Copepoda. Bull. Plankton Soc. Japan, Spec. Vol: 515-525

Ogilvie, H. S. (1953). Copepod nauplii (I). Cons. Int. Explor. Mer, Zooplankton Sheet 50

Paul, A. J., Coyle, K. O., Haldorson, L. (1991). Interannual variations in copepod nauplii prey of larval fish in an Alaskan Bay. ICES J, mar. Sci. 48: 157-165

Paul, A. J., Coyle, K. O., Ziemann, D. A. (1990). Variations in egg production rates by Pseudocalanus spp. in a subarctic Alaskan bay during the onset of feeding by larval fish. J. Crust. Biol. 10: 648-658

Ponton, D., Fortier, L. (1992). Vertical distribution and foraging of marine fish larvae under the ice cover of southeastern Hudson Bay. Mar. Ecol. Prog. Ser. 81: 215-227

Ponton, D., Gagné, J. A., Fortier, L. (1993). Production and dispersion of freshwater, anadromous, and marine fish larvae in and around a river plume in subarctic Hudson Bay, Canada. Polar Biol. 13: 321-331

Prinsenberg, S. J. (1986). The circulation pattern and current structure of Hudson Bay. In: Martini, I. P. (ed.) Canadian Inland Seas. Elsevier, Amsterdam, p. 187-204

Purcell, J. E. (1990). Soft-bodied zooplankton predators and competitors of larval herring (Clupea harengus pallasi) at herring spawning grounds in British Columbia. Can. J. Fish. Aquat. Sci. 47: 505-515

Runge, J. A. (1988). Should we expect a relationship between 
primary production and fisheries? The role of copepod dynamics as a filter of trophic variability. Hydrobiol. 167/168: $61-71$

Runge, J. A., Ingram, R. G. (1991). Under-ice feeding and diel migration by the planktonic copepods Calanus glacialis and Pseudocalanus minutus in relation to the ice algal production cycle in southeastern Hudson Bay. Mar. Biol. 108: $217-225$

Runge, J. A., Therriault, J.-C., Legendre, L., Ingram, R. G., Demers, S. (1991). Coupling between ice microalgal productivity and the pelagic, metazoan food web in southeastern Hudson Bay: a synthesis of results. In: Sakshaug, E., Hopkins, C. C. E., Øritsland, N. A. (eds.) Proceedings of the Pro Mare Symposium on Polar Marine Ecology, 12-16 May 1990. Polar Res. 10: 325-338

Shepherd, J. G., Cushing, D. H. (1980). A mechanism for density-dependent survival of larval fish as the basis of a stock-recruitment relationship. J. Cons. int. Explor. Mer 39: $160-167$

Sherman, K., Smith, W., Morse, W., Berman, M., Green, J., Ejsymont, L. (1984). Spawning strategies of fishes in relation to circulation, phytoplankton production, and pulses in zooplankton off the northeastern United States. Mar. Ecol. Prog. Ser. 18: 1-19

Sinclair, M. (1988). Marine populations: an essay on popula-

This article was submitted to the editor tion regulation and speciation. University of Washington Press, Seattle

Sinclair, M., Tremblay, M. J. (1984). Timing of spawning of Atlantic herring (Clupea harengus harengus) populations and the match-mismatch theory. Can. J. Fish. Aquat. Sci. 41: 1055-1065

Sundby, S., Fossum, P. (1990). Feeding conditions of ArctoNorwegian cod larvae compared with the RothschildOsborn theory on small-scale turbulence and plankton contact rates. J. Plankton Res. 12: 1153-1162

Suthers, I. M., Frank, K T., Campana, S. E. (1989). Spatial comparison of recent growth in postlarval Atlantic cod (Gadus morhua) off southwestern Nova Scotia: inferior growth in a presumed nursery area. Can. J. Fish. Aquat. Sci. 46 (Suppl. 1): 113-124

Sverdrup, H. U. (1953). On conditions for the vernal blooming of phytoplankton. J. Cons. int. Explor. Mer 18: 287-295

Tremblay, C., Runge, J. A., Legendre, L. (1989). Grazing and sedimentation of ice algae during and immediately after a bloom at the ice-water interface. Mar. Ecol. Prog. Ser. 56 $291-300$

Young, J. W., Davis, T L. O. (1992). Feeding ecology and interannual variations in diet of larval jack mackerel, Trachurus declivis (Pisces: Carangidae), from coastal waters of eastern Tasmania. Mar. Biol. 113: 11-20

Manuscript first received: June 14, 1994

Revised version accepted: December 20, 1994 